LINGUISTIK : Jurnal Bahasa \& Sastra

http://jurnal.um-tapsel.ac.id/index.php/Linguistik

\title{
PENGARUH MODEL PEMBELAJARAN SINEKTIK DAN PENGUASAAN DIKSI TERHADAP KETERAMPILAN MENULIS PUISI SISWA KELAS X SMA DHARMAWANGSA MEDAN
}

\author{
Elisa Rambe NIDN.1313029002 \\ Email: elisarambe@stkipuskutacane.ac.id \\ STKIP USMAN SAFRI KUTACANE
}

\begin{abstract}
ABSTRAK
Penelitian ini bertujuan untuk mengetahui "Pengaruh model pembelajaran sinektik dan penguasaan diksi terhadap keterampilan menulis puisi". Populasi penelitian ini adalah seluruh siswa kelas X SMA Dharmawangsa Medan yang terdiri dari empat kelas dengan jumlah siswa sebanyak 153 orang. Pemilihan SMA Dharmawangsa Medan sebagai populasi penelitian berdasarkan asumsi bahwa siswa-siswi tersebut memiliki karakteristik yang relatif sama. Teknik pengambilan sampel menggunakan random kelas dengan sistem undi atau lotre. Sampel penelitian ini adalah 60 siswa yang terdiri dari dua kelas yaitu kelas XA dan kelas XB. Menggunakan metode eksperimen semu (quasi eksperimen) dengan desain penelitian faktorial $2 \times 2$. Instrumen penelitian tes. Teknik analisis data menggunakan adalah teknik statistik deskriptif dan inferensial. Hasil analisis menunjukkan bahwa siswa dengan Sinektik skor rata-rata keterampilan menulis puisi sebesar 35,433, adapun untuk kelompok siswa dengan Konvensional skor rata-rata keterampilan menulis puisi sebesar 33,167. Hal ini berarti bahwa penerapan Sinektik memberikan pengaruh yang lebih baik daripada Konvensional. Hasil analisis menunjukkan kelompok siswa dengan penguasaan diksi tinggi skor rata-rata keterampilan menulis puisi sebesar 36,8 adapun skor rata-rata keterampilan menulis puisi dengan penguasaan diksi rendah sebesar 31,83 . Hal ini berarti penguasaan diksi terbukti mempunyai pengaruh yang signifikan terhadap pencapaian keterampilan menulis puisi.
\end{abstract}

Kata kunci: Diksi, Keterampilan Menulis Puisi, dan Sinektik

\section{PENDAHULUAN}

Menulis puisi merupakan
salah satu kompetensi dasar yang
harus dimiliki oleh siswa dalam
pelajaran Bahasa Indonesia. Dalam
meningkatkan keterampilan menulis
puisi, siswa harus mampu untuk
e-ISSN 25489402

mengungkapkan gagasan, pendapat, dan perasaan kepada pihak lain dengan menggunakan bahasa tulis yang bersifat literer. Hal ini maksudnya bahwa kemampuan menulis puisi mengharuskan siswa untuk memiliki kreatifitas dalam Vol.4 No.1 Januari - Juni 2019/18 
mengungkapkan gagasan, pendapat, dan perasaan.

Dalam pengajaran Bahasa Indonesia khususnya dalam menulis puisi, masih banyak dijumpai siswa yang kurang kreatif berpikir sehingga siswa tidak mampu mengungkapkan gagasan, pendapat, dan perasaan dalam menulis puisi sehingga nilai keterampilan menulis puisi siswa belum mencapai KKM yaitu 70 . Rendahnya kemampuan siswa dalam menulis puisi sudah tentu memberi efek yang buruk bagi pendidian Bahasa Indonesia di sekolah. Oleh karena itu perlu adanya model pembelajaran yang inovatif yang mampu membangkitkan kreatifitas siswa dalam mengungkapkan gagasan, pendapat, dan perasaan sehingga makna puisi dapat menyentuh perasaan orang yang mendengar.

Model pembelajaran sinektik dirancang agar siswa mampu memecahkan masalah (problem solver) dan untuk mengembangkan produksi (product development) sehingga tumbuh kreativitas siswa dalam mengatasi permasalahan yang terjadi. Hal ini dimaksudkan bahwa

e- ISSN 25489402 dengan model pembelajaran sinektik, siswa mampu berfikir kreatif untuk membuat hasil pembelajaran lebih baik lagi. Dalam hal ini keterampilan menulis puisi melalui analogi.

Diksi merupakan pilihan kata yang tepat dan selaras dalam penggunaannya untuk mengungkapkan gagasan sehingga diperoleh efek tertentu (seperti yang diharapkan). Diksi juga berarti kemampuan memilih kata dengan cermat sehingga dapat membedakan secara tepat nuansa-nuansa makna gagasan yang ingin disampaikan, kemampuan untuk menemukan bentuk yang sesuai dengan situasi dan nilai rasa.

Diksi dalam menulis puisi dibutuhkan kemampuan untuk memilih kata-kata yang tepat sehingga dapat mewakili dan menggambarkan hal-hal yang dikehendakinya. Menyusun kata-kata dengan cara sedemikian rupa sehingga artinya menimbulkan imajinasi estetik. Penguasaan diksi yang baik dalam menulis puisi merupakan suatu proses yang sudah tentu memberikan hasil yang diharapkan ialah nilai kepuitisan.

Vol.4 No.1 Januari - Juni 2019/19 
Berdasarkan penjelasan di atas, dapat disimpulkan bahwa pengaruh model pembelajaran sinektik dan penguasaan diksi akan meningkatkan ketrampilan menulis puisi siswa. Oleh karena itu sangat penting untuk membahasa penelitian ini lebih lanjut sebagai informasi penting bagi guru dalam memecahkan masalah siswa di sekolah khususnya pembelajaran Bahasa Indonesia.

Rumusan masalah pada penelitian ini disusun dalam bentuk pertanyaan,

Apakah ada pengaruh model pembelajaran sinektik terhadap keterampilan menulis puisi siswa kelas X SMA Dharmawangsa Medan ?Apakah ada pengaruh penguasaan diksi terhadap keterampilan menulis puisi siswa kelas $\mathrm{X}$ SMA Dharmawangsa Medan ?Apakah ada pengaruh model pembelajaran sinektik dan penguasaan diksi terhadap keterampilan menulis puisi siswa kelas X SMA Dharmawangsa Medan?

e- ISSN 25489402

\section{PEMBAHASAN}

Secara umum istilah "model" diartikan sebagai kerangka konseptual yang digunakan sebagi pedoman dalam melakukan suatu kegiatan. Dalam Kamus Besar Bahasa Indonesia (2005:751), "Model adalah pola (contoh, acuan, ragam, dan sebagainya) dari sesuatu yang dibuat atau dihasilkan." Hal ini dimaksudkan bahwa "Pembelajaran" merupakan upaya untuk meningkatkan suatu proses belajar.

Jadi, dapat disimpulkan bahwa model pembelajaran adalah suatu pola pendekatan yang menyeluruh yang dapat digunakan untuk mendesain suatu pembelajaran. Pendekatan tersebut akan menghasilkan situasi lingkungan belajar yang menyebabkan siswa berinteraksi.

Model pembelajaran adalah cara-cara mengajar yang dipergunakan oleh seorang guru atau instruktur. Dengan kata lain dapat dijelaskan bahwa model pengajaran adalah teknik penyajian yang dikuasai guru untuk meng : atau menyajikan bahan pelajaran pada siswa di dalam kelas, baik secara

Vol.4 No.1 Januari - Juni 2019/20 
individual maupun secara kelompok. Agar pelajaran itu dapat diserap, dipahami dan dimanfaatkan oleh siswa dengan baik.

Tabel 2.1

Proses Pembelajaran dengan Menggunakan Model Pembelajaran Ceramah

\begin{tabular}{|c|l|}
\hline Tahap & \multicolumn{1}{|c|}{ Kegiatan } \\
\hline 1 & Menyampaikan materi \\
\hline 2 & Tanya jawab \\
\hline 3 & $\begin{array}{l}\text { Memberikan tugas } \\
\text { kepada siswa }\end{array}$ \\
\hline 4 & Membahas tugas \\
\hline 5 & Menyimpulkan materi \\
\hline 6 & Pemberian evaluasi \\
\hline
\end{tabular}

\section{Jika dilihat dari tiga jalur} modus penyampaian pesan pembelajaran, penyelenggaraan pembelajaran konvensional lebih sering menggunakan modus telling (pemberian informasi), ketimbang modus demonstrating (memperagakan), dan doing direct performance (memberikan kesempatan untuk menampilkan unjuk kerja secara langsung). Dalam kata lain, guru lebih sering menggunakan strategi atau metode ceramah atau drill dengan mengikuti

e- ISSN 25489402 urutan materi dalam kurikulum secara ketat. Guru berasumsi bahwa keberhasilan program pembelajaran dilihat dari ketuntasannya menyampaikan seluruh meteri yang ada dalam kurikulum.

Model pembelajaran sinektik ini pertama kali diperkenalkan dan diuji coba oleh William J.J. Gordon untuk meningkatkan kinerja perusahaan melalui pengembangan pribadi yang terinteraksi dengan kepribadian yang kompeten. Yusuf (2008: 69) mengatakan bahwa model sinektik ini beriorentasi pada pengembangan pribadi dan keunikan individu, diutamakan penekanannya pada proses membantu individu dalam membentuk dan mengorganisasikan realita yang unik. Kelebihan lain dari model ini adalah lebih banyak memperhatikan kehidupan pada emosional siswa. Joyce (2011:257) mengatakan ada dua strategi dalam model pengajaran yang didasarkan pada prosedurprosedur sinektik. Salah satu dari dua strategi tersebut, yakni membuat sesuatu yang baru (creating something new), dirancang untuk membuat hal-hal yang familiar Vol.4 No.1 Januari - Juni 2019/21 
menjadi asing, untuk membantu siswa melihat masalah-masalah, gagasan-gagasan, dan hasil-hasil yang lama dengan cara yang baru, pandangan yang lebih kreatif.

$$
\text { Untuk mengetahui }
$$

pengembangan kreativitas siswa dengan model pembelajaran sinektik dapat dilihat pada bagan proses belajar mengajar di bawah ini:

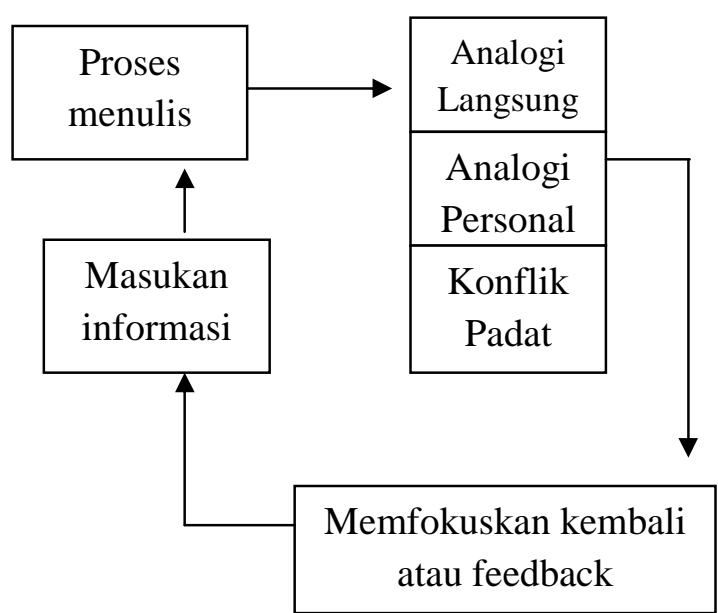

Gambar 2.1 Proses Belajar Mengajar Model Pembelajaran Sinektik

Keterangan pada gambar proses belajar mengajar model pembelajaran sinektik, yaitu:

1. Tahap Pertama: Mendeskripsikan Situasi Saat Ini

Guru meminta siswa mendeskripsikan situasi atau

e- ISSN 25489402 topik seperti yang mereka lihat saat ini.

2. Tahap Kedua: Analogi Langsung

Siswa mengusulkan analogianalogi langsung, memilihnya, dan mengeksplorasi (mendeskripsikan)-nya lebih jauh.

Analogi langsung merupakan perbandingan dua objek atau konsep. Perbandingan tidak harus selalu identik dalam segala hal. Fungsinya cukup sederhana, yaitu untuk mentransposisikan kondisi-kondisi topik atau situasi permasalahannya yang asli pada situasi lain untuk menghadirkan pandangan baru tentang gagasan atau masalah. Analogi langsung dimunculkan melalui pertanyaanpertanyaan yang menuntut adanya perbandingan secara langsung.

Contoh: Bagaimana sebuah jeruk seperti benda hidup ?

Bagaimana jika sekolah seperti selada?

3. Tahap Ketiga: Analogi Personal

Siswa "menjadi" analogi yang telah mereka pilih dalam tahap kedua tadi.

Vol.4 No.1 Januari - Juni 2019/22 


\section{Tahap Keempat: Konflik Padat}

Siswa mengambil deskripsideskripsi dari tahap kedua dan ketiga, mengusulkan beberapa analogi konflik padat, dan memilih salah satunya.

5. Tahap Kelima: Anologi Langsung

Siswa membuat dan memilih anologi langsung yang lain, yang didasarkan pada analogi konflik padat.

6. Tahap Enam: Memeriksa Kembali Tugas Awal

Guru meminta siswa kembali pada tugas atau masalah awal dan menggunakan anologi terakhir dan atau seluruh pengalaman sinektiknya. ( Sumber Gordon, dalam Bruce dkk, 2011: 258).

Menurut Hamalik (2001:84), model pembelajaran sinektik mempunyai kelebihan, antara lain :

a. Model ini bermanfaat karena untuk mengembangkan pengertian baru pada diri siswa tentang sesuatu masalah sehingga dia sadar bagaimana bertingkah laku dalam situasi tertentu.

e- ISSN 25489402 b. Model ini bermanfaat karena dapat mengembangkan kejelasan pengertian dan internalisasi pada diri siswa tentang materi baru.

c. Model ini dapat mengembangkan berfikir kreatif, baik pada diri siswa maupun pada guru.

d. Model ini dilaksanakan dalam suasana kebebasan intelektual dan keamanan martabat antara siswa.

e. Model ini membantu siswa menemukan cara berfikir baru dalam memecahkan suatu masalah.

Selain kelebihan-kelebihan yang telah dijelaskan di atas, model pembelajaran sinektik juga memiliki beberapa kekurangan, antara lain:

a. Model pembelajaran ini sulit dilaksanakan bagi guru dan siswa yang sudah terbiasa melaksanakan pola penyampaian informasi pembelajaran dengan menggunakan teknik konvensional.

b. Karena model ini menitikberatkan pada berpikir Vol.4 No.1 Januari - Juni 2019/23 
LINGUISTIK : Jurnal Bahasa \& Sastra

http://jurnal.um-tapsel.ac.id/index.php/Linguistik

reflektif dan imajinatif dalam

kegiatan yang terjadi dalm situasi tertentu, aka ada kemungkinan siswa kurang menguasai fakta-fakta dan prosedur melaksanakan keterampilan.

c. Model ini menuntut agar guru mampu menempatkan diri sebagai pemrakarsa dan pembimbing, namun banyak guru yang tentu memiliki hal tersebut.

d. Dibutuhkan waktu yang cukup lama karena siswa harus merespon taha demi tahap langkah-langkah pembelajaran ini.

(Sumber: Sugiyono, 2013: 409)

\section{HASIL PENELITIAN}

Berikut ini disajikan secara berturut-turut gambaran deskripsi data mengenai Keterampilan Menulis Puisi melalui Model Pembelajaran Sinektik terhadap Penguasaan Diksi yang tinggi dan rendah maupun yang memakai Model Pembelajaran Konvensional terhadap siswa yang memiliki Penguasaan Diksi Tinggi dan Rendah. Skor Keterampilan e- ISSN 25489402
Menulis Puisi yang diajar dengan Sinektik yang dikelompokkan atas Penguasaan Diksi tinggi dan rendah akan di deskripsi dengan menginformasikan rata-rata (mean), median, varians, simpangan baku, skor maksimum dan skor minimum dan dilengkapi dengan tabel distribusi frekuensinya dan grafik histogram.

$$
\text { Hasil analisis mengenai }
$$

Keterampilan Menulis Puisi dengan Sinektik diketahui bahwa: skor tertinggi 44 dan skor terendah 27 sehingga rentangan skor 27-44. Kemampuan Menulis Puisi dalam kelompok ini mempunyai skor ratarata (mean) sebesar 35,13; skor modus sebesar 37,5 ; skor median sebesar 35,5 dan simpangan baku (standar deviasi) sebesar 4,64.

Hasil pengujian hipotesis diketahui bahwa ada pengaruh model pembelajaran sinektik terhadap keterampilan menulis puisi siswa kelas X SMA Darmawangsa Medan yaitu sebesar 35,433. Hasil ini menunjukkan bahwa model pembelajaran sinektik sangat membantu siswa dalam menulis puisi

Vol.4 No.1 Januari - Juni 2019/24 
dengan mendeskripsikan situasi, yang signifikan terhadap pencapaian analogi langsung, analogi personal, Keterampilan Menulis Puisi. kjonflik padat, analogi langsung awal, dan memeriksa kembali tugas yang telah dilakukan oleh siswa dalam menulis puisi. Dengan kata lain dapat disimpulkan bahwa model pembelajaran sinektik sangat membantu siswa menulis puisi dengan pengembangan kreativitas siswa melalui analogi.

\section{Hasil uji hipotesis}

menunjukkan bahwa kelompok siswa yang memiliki Penguasaan Diksi Tinggi terbukti memberikan pengaruh yang lebih baik dalam pencapaian Keterampilan Menulis Puisi dibandingkan dengan kelompok siswa yang memiliki Penguasaan Diksi Rendah. Hasil analisis menunjukkan bahwa kelompok siswa dengan Penguasaan Diksi Tinggi skor rata-rata Keterampilan Menulis Puisi sebesar 36,8 adapun skor rata-rata Kemampuan Menulis Puisi dengan Penguasaan Diksi Rendah sebesar 31,83. Hal ini berarti Penguasaan Diksi terbukti mempunyai pengaruh

e- ISSN 25489402
Hasil analisis menunjukkan $\mathrm{p}$ $=0,001<0,05$ sehingga hipotesis nol ditolak. Hal ini membuktikan terdapat interaksi pengaruh yang signifikan, penggunaan model pembelajaran sinektik dan penguasaan diksi terhadap keterampilan menulis puisi.

Berdasarkan dari uji lanjut yaitu uji Tuckey maka dapat dilihat bahwa Sinektik disertai dengan Penguasaan Diksi Tinggi akan lebih memudahkan siswa dalam meningkatkan Keterampilan Menulis Puisi dibandingkan dengan Ceramah dan Penguasaan Diksi Rendah. Hal ini disebabkan bahwa penerapan Sinektik dan disertai dengan Penguasaan Diksi Tinggi akan lebih memudahkan siswa dalam mengungkapkan kalimat yang tepat dimana siswa dapat mencocokkan kalimat sesuai dengan konteks dan makna dalam puisi yang dimaksud oleh penyair. Peranan guru selain menerapkan model pembelajaran yang tepat dalam mendesain kegiatan pembelajaran juga harus dapat

Vol.4 No.1 Januari - Juni 2019/25 
memanfaatkan model pembelajaran yang dapat membantu siswa dalam meningkatkan keterampilan menulis puisi lebih baik dan benar.

\section{SIMPULAN}

Berdasarkan hasil penelitian
yang telah diuraikan pada bab
sebelumnya, maka dapat ditarik
beberapa kesimpulan sebagai
berikut:

1. Ada pengaruh model pembelajaran sinektik terhadap keterampilan menulis puisi siswa kelas $\mathrm{X}$ SMA Dharmawangsa Medan.

2. Ada pengaruh penguasaan diksi terhadap keterampilan menulis puisi siswa kelas $\mathrm{X}$ SMA Dharmawangsa Medan.

3. Ada interaksi antara model pembelajaran sinektik dan penguasaan diksi terhadap keterampilan menulis puisi siswa kelas $\mathrm{X}$ SMA Dharmawangsa Medan.

Hasil penelitian diatas menunjukkan bahwa pelaksanaan model pembelajaran dengan menggunakan Sinektik dan Ceramah

e- ISSN 25489402 dengan memperhatikan Penguasaan Diksi sangat mempengaruhi Keterampiilan Menulis Puisi. Oleh karena itu implikasi hasil penelitian adalah :

1. Implikasi Teoritis

a. Hasil penelitian ini menunjukkan bahwa Model Pembelajaran dan Penguasaan Diksi mempengaruhi Keterampilan Menulis Puisi. Hal ini dapat digunakan sebagai bahan kajian atau teori yang dapat melengkapi hasil penelitian dibidang pendidikan lainnya.

b. Hasil penelitian dapat memperkaya wawasan pengembangan ilmu pengetahuan yang berhubungan dengan dunia pendidikan terutama dalam meningkatkan efektivitas dan kualitas dalam pengembangan Model Pembelajaran khususnya dalam pendidikan Bahasa Indonesia.

\section{Implikasi Praktis}

a. Hasil penelitian ini dapat digunakan sebagai pedoman bagi Guru bahasa Indonesia untuk meningkatkan Keterampilan Menulis Puisi.

Vol.4 No.1 Januari - Juni 2019/26 
LINGUISTIK : Jurnal Bahasa \& Sastra

http://jurnal.um-tapsel.ac.id/index.php/Linguistik

b. Guru harus dapat memilih, menentukan dan menerapkan Model Pembelajaran dalam penyampaian materi pelajaran khususnya dalam Keterampilan Menulis Puisi.

c. Siswa baik yang memiliki Penguasaan Diksi Tinggi semakin memiliki kesadaran tentang pentingnya Model Pembelajaran sebagai cara atau pendekatan dalam proses belajar pengajar.

\section{DAFTAR PUSTAKA}

Ambarita, K. 2008. Teknik Penulisan Puisi. Jakarta; Genexa

Aminuddin. 2002. Pengantar Apresiasi Karya Sastra. Bandung; Sinar Baru

Arifin, T. 2008. Tata Bahasa Baku Bahasa Indonesia. Jakarta: Balai Pustaka.

Arikunto, Suharsimi. 2006. Prosedur Penelitian Suatu Pendekatan Praktik. Jakarta: Rineka Cipta.

Dahlan, S. 2004. Belajar dengan Pendekatan PAILKEM: Pembelajaran Aktif, Inovatif, Lingkungan, Kreatif, Efektif,
Menarik, Jakarta: Bumi Aksara

Depdiknas. 2005. Kamus Besar Bahasa Indonesia. Jakarta: Balai Pustaka.

Depdikbud. 2000. Kamus Besar Bahasa Indonesia. Jakarta: Balai Pustaka.

Djamarah, S. 2001. Belajar dan Pembelajaran. Jakarta: PT Rineka Cipta

Endarwarsa. $2005 . \quad$ Strategi Pembelajaran. Jakarta: Depdiknas.

Freire, M. 2002. Efektiveness of Teaching Learning Process. New York; Moughton.

Gie. 2002. Keterampilan Menulis. Jakarta ; Gramedia

Hamalik, O. 2001. Strategi Pembelajaran Modern . Jakarta: Depdiknas

Joice, B dan Weil, M. 2003. Teaching Learning Model. New York; Longman.

Joyce, B. 2011. Models of Teaching Edisi Kedelapan. Boston: Allyn and Bacon.

Juidah, Imas. 2012. Pembelajaran Menulis Puisi dengan Model Sinektik pada Siswa Kelas X SMA Negeri 1 Sindang Indramayu. Jurnal Pendidikan. 
LINGUISTIK : Jurnal Bahasa \& Sastra

http://jurnal.um-tapsel.ac.id/index.php/Linguistik

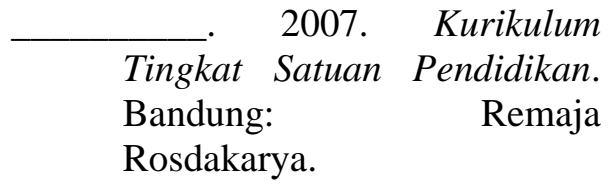

Keraf, Gorys. 2001. Komposisi.Ende Flores: Nusa Indah

Kosasih, E. 2009. Mantap Bersastra Indonesia. Bandung: Yrama Widya.

Nur Ain, Rumaratu. 2009. Meningkatkan Hasil Belajar IPS Dengan Menggunakan Model Sinektik Siswa Kelas IV SDN Martopuro II Kecamatan Purwosari Kabupaten Pasuruan. Jurnal Pendidikan

Poerwadarminta. 2005. Psikologi Pendidikan. Yogyakarta: UPP IKIP Yogyakarta

Poteet. 2004. Writing as a Skill. London; Longman

Purba, G. 2011. Kemampuan Membaca Puisi. Jogjakarya; Hindinita

Putrayasa, K. 2009. Belajar dan Pembelajaran. Jakarta: Rineka Cipta.

Sadikin .2010. Apresiasi Karya Sastra. Jakarta ; Gemilang

Sudjana, N dan Suwariyah. 2002. Dasar-dasar Proses Belajar Mengajar. Bandung: Sinar Baru Algesindo.

Sugiarto, Siagian, D., Sunaryanto, L.T., Oetomo, D.S. (2003).
Teknik Sampling. Jakarta : PT Gramedia Pustaka Utama.

Sugiyono. 2009. Metode Penelitian Kuantitatif Kualitatif dan $R \& D$. Bandung: $\mathrm{CV}$. Alfabeta.
------------. 2010. Statistik untuk Penelitian. Bandung: Alfabeta Bandung.

Sugiyono. 2011. Metode Penelitian Kuantitatif Kualitatif dan $R \& D$. Bandung: Alfabeta. -2012. Metode Penelitian Pendidikan Pendekatan Kuantitatif, Kualitatif dan $R \& D$. Bandung: Alfabeta.

Sukandi, B. 2003. Penerapan Pendekatan Sains Teknologi Masyarakat Dalam Pembelajaran Sains Di Sekolah Dasar. Yogyakarta: Universitas Sanata Dharma.

Sunarto, C. 2009. Model Pembelajaran. Jakarta : Bumi Aksara

Tarigan, Henry Guntur. 2003. Menulis Sebagai Suatu Keterampilan Berbahasa. Bandung: Angkasa.

Waluyo, Herman. 2005. Apresiasi Puisi. Jakarta: PT Gramedia Pustaka Umum

Wijaya, S. 2008. Model-model Pembelajaran Inovatif Berorientasi Konstruktivistik. Jakarta: Prestasi Pustaka Publisher.

Vol.4 No.1 Januari - Juni 2019/28 
LINGUISTIK : Jurnal Bahasa \& Sastra

http://jurnal.um-tapsel.ac.id/index.php/Linguistik

Winaputra, 2005. Model

Pembelajaran. Jakarta : PT

Gramedia.

Yusuf, N. 2008. Penerapan Model

Pembelajaran Sinektik untuk

meningkatkan kreativitas

siswa SMK Negeri 1

Lamongan pada Kompetensi

Dasar Mengolah Hidangan

dari telur, unggas, daging.

Skripsi. 